\title{
Free Radical Scavenging Activity and Preliminary Phytochemical Screening of Ethylacetate Fraction of Stem Bark of Lannea acida (A. Rich)
}

\author{
Onoshe Solomon ${ }^{1}{ }^{*}$, M.M. Azubuike², Louis Hitler ${ }^{3}$, I.E. Oghenekevwe ${ }^{1}$, M.A. Mary ${ }^{4}$, P.I. Amos ${ }^{5}$ \\ ${ }^{1}$ Department of Biochemistry, Usmanu Danfodiyo University, Sokoto, Nigeria. \\ 2Department of Biochemistry, School of Life sciences, Modibbo Adama University of Technology, Yola, Nigeria. \\ ${ }^{3}$ CAS Key Laboratory of Nanosystem and Hierarchical Fabrication, CAS Centre for Excellence in Nanoscience, National Centre for Nanoscience and \\ Technology, University of Chinese Academy of Sciences, Beijing 100191, China. \\ ${ }^{4}$ Department of Biological Sciences, Federal University Kashere, Gombe, Nigeria. \\ ${ }^{5}$ Department of Chemistry, Faculty of Physical Sciences, Modibbo Adama University of Technology, Yola, Adamawa State, Nigeria.
}

\section{ART ICLE DETAILS}

\section{Article history:}

Received 11 June 2018

Accepted 20 June 2018

Available online 07 July 2018

Keywords:

Lannea acida

2,2-Diphenyl-1-picrylhydrazyl

Free Radicals

\begin{abstract}
A B S T R A C T
The present study was designed to investigate the free radical scavenging activity and phytochemical composition of ethylacetate fraction (EtyAc) of stem bark of Lannea acida. The free radical scavenging activity was tested using 2,2-diphenyl-1-picrylhydrazyl (DPPH) and by determination of total phenolic composition. Preliminary phytochemical screening was carried out using standard methods. The EtyAc fraction demonstrated significant scavenging activity, contained appreciable amounts of total phenolics and a number of secondary plant metabolites including, flavonoids, alkaloids, tannins and saponins. The study revealed that EtyAc fraction of stem bark of Lannea acida possesses significant antioxidant activity.
\end{abstract}

\section{Introduction}

The deleterious effects of free radicals in various human diseases such as diabetes mellitus, gastric ulcer, neurodegenerative disorders, viral infections and cancer have been widely reported [1-3]. Free radicals are atoms or groups of atoms with unpaired electrons and can be formed when oxygen interacts with certain molecules [4]. They may be either oxygen derived (ROS, reactive oxygen species) or nitrogen derived (RNS, reactive nitrogen species) [5].

In the last two decades, efforts to find natural antioxidants from plant sources have increased. Antioxidants are chemical substances that inhibit the propagation of free radical reactions and thus protect the human body from diseases [6]. There are many synthetic antioxidants in use. It is reported, however, they have several adverse effects $[7,8]$. Therefore there is a need for less toxic, more and cost effective antioxidants. Plants appear to have these desired effects.

Lannea acida (A. Rich) is a small deciduous shrub or tree belonging to the family Anacardiaceae [9]. It is known as "Faru" among the Hausa's in Nigeria. It is a valuable multi-purpose tree widely used by local people. The bark is used in the treatment of stomach troubles, beriberi, schistosomiasis and haemorrhoids [10]. The leaves and bark have been reported to be useful in the treatment and management of gout, rheumatism, wounds, swelling and burns [11].

\section{Experimental Methods}

\subsection{Plant Collection and Identification}

The fresh stem bark of Lannea acida was collected from Zuru town in Kebbi State, Nigeria. The plant was authenticated by a Taxonomist from Botany Unit in Biological Science Department, Usmanu Danfodiyo University Sokoto where a voucher specimen has been deposited.

\subsection{Preparation of Plant Extracts}

The preparation of extract was carried out according to the method of Hassan et al. [12]. Briefly, the stem bark of the plant collected was cleaned,

air dried at room temperature and then cut into small pieces. Two hundred grams (200 g) of sample was macerated using $2 \mathrm{~L}$ of $95 \%$ methanol for 48 hours and was filtered with Whatman No.1 filter paper. The filtrate was concentrated in a rotary evaporator at $45^{\circ} \mathrm{C}$. The dried extract was kept in a dried clean air tight container until used.

\subsection{Fractionation of Extract}

About fifty grams ( $50 \mathrm{~g}$ ) of the crude methanol stem bark residue was subjected to fractionation by solubilisation with water in a separatory funnel and sequential partition with hexane $(3 \times 200 \mathrm{~mL})$, ethyl acetate $(3 \times 200 \mathrm{~mL})$ and saturated butanol $(3 \times 200 \mathrm{~mL})$. Each fraction was evaporated to dryness and this EtyAc fraction was used for the study.

\subsection{Phytochemical Screening}

Qualitative phytochemical screening to test for the presence of alkaloids, anthraquinones, resins, flavonoids, glycosides, phenols, saponins, saponin glycosides, steroids, tannins, terpenoids and volatile oils were conducted using standard methods described by some researchers [13-17].

\subsection{Free radical Scavenging Activity}

\section{2,2-Diphenyl-1-picrylhydrazyl (DPPH•) Free Radical Scavenging Activity}

DPPH free radical scavenging activity was investigated by the method of McCune and Johns [18].

\subsection{Total Phenolic Contents}

The amount of total phenol content was determined by Folin-Ciocateu reagent method [19-21].

\section{Results and Discussion}

Preliminary phytochemical screening of the EtyAc fractions is presented in Table 1. Steroids, cardiac glycosides, alkaloids, terpenoids, flavonoids, tannins, saponins and phenols were detected. Anthraquinone glycosides and resins were not detected.

Phytochemical studies of other Lannea species also reported the presence of flavonoids, tannins, alkaloids, saponins and phenols [22-24].

\footnotetext{
(25-
} 
Tannin-rich plant extracts have been widely used for the treatment of gastric ulcer disease [25]. Flavonoids have been reported to exhibit; antisecretor [26], antiulcer properties [27], antioxidant [28] and antiinflammatory activities [29]. Several biological activities are associated with plants alkaloids among which are antiulcer, antitumor, diuretic, antihypertensive, and anti-inflammatory [30].

Figs. 1-3 present the results of quantitative phytochemical screening, total phenolic content and DPPH scavenging activity and ascorbic acid at different studied concentrations respectively. The total phenolic content varied from $15.08 \pm 1.22$ to $38.21 \pm 2.01 \mathrm{GAE} / 100 \mathrm{~g}$. The fraction exhibited the highest percent scavenging activity at $20 \mathrm{mg} / \mathrm{mL}$. The concentration of $2.5 \mathrm{mg} / \mathrm{mL}$ yielded the lowest activity. The scavenging effect increased with increasing concentration of the fraction. However, scavenging activity of ascorbic acid, a well-known antioxidant, was relatively more pronounced than that of the EtyAc fraction at $2.5,5$ and $10 \mathrm{mg} / \mathrm{mL}$. The percentage DPPH scavenging activity of the EtyAc fraction at $20 \mathrm{mg} / \mathrm{mL}$ was comparable to ascorbic acid.

Table 1 Qualitative phytochemical constituents EtyAc of Lannea acida

\begin{tabular}{lc}
\hline Phytochemical & EtyAc \\
\hline Flavonoids & + \\
Tannins & + \\
Saponins & + \\
Steroids & + \\
Phenols & + \\
Anthraquinones glycosides & - \\
Cardiac Glycosides & + \\
Alkaloids & + \\
Volatile Oils & - \\
Terpenoids & + \\
Resins & - \\
\hline
\end{tabular}

Key: -= Not Detected, $+=$ Present

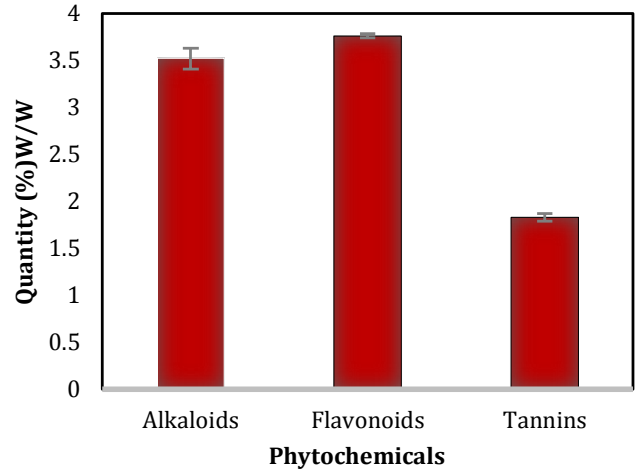

Fig. 1 Quantitative phytochemical composition of EtyAc of Lannea acida

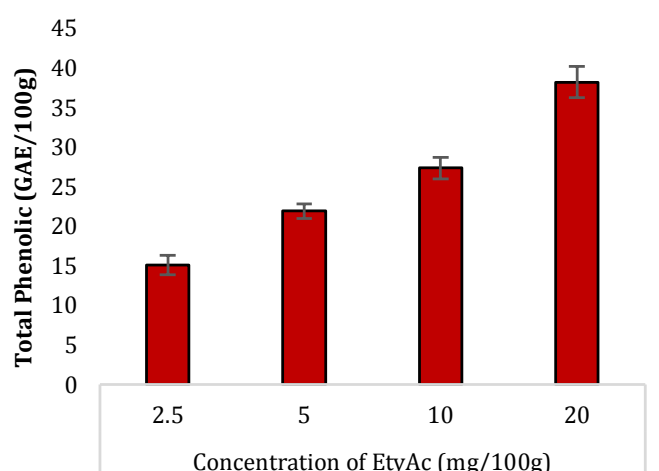

Fig. 2 Total phenolic content of EtyAc fraction of stem bark of Lannea acida

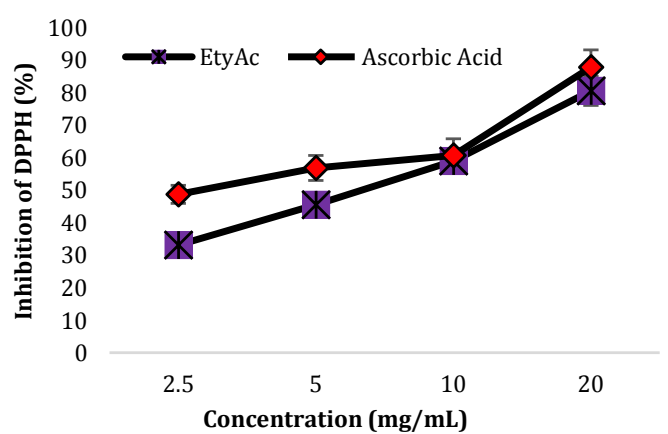

Fig. 3 Percentage DPPH scavenging activity of EtyAc fraction of Lannea acida and ascorbic acid
From the results, appreciable amount of phenolic compounds were detected in the EtyAc fraction. Phenolic compounds constitute one of the major groups of substances acting as primary antioxidants or free radical terminators. They exhibit their antioxidant activity by various mechanisms such as donation of hydrogen atoms to free radicals and through connection to transition metal ions resulting in more stable forms [21].

A rapid, simple and inexpensive method for the antioxidant screening of plant extracts involves the use of the free radical DPPH. DPPH is a stable nitrogen-centered free radical that changes colour from violet to yellow upon reduction by either the process of hydrogen- or electron- donation. Substances which are able to perform this reaction can be considered as antioxidants and therefore free radical scavengers [31]. The result of DPPH scavenging activity assay in this study indicates that the EtyAc fraction possess significant activity. The free radical scavenging activity increased with increasing concentration. This activity correlated well with the high amount of total phenolic and flavonoids. Usually, substances with high level of phenolic contents and flavonoids demonstrate good free radical scavenging activity [32]. These findings suggests that the EtyAc fraction contains compounds that are capable of donating hydrogen to a free radical in order to remove odd electron which is responsible for radical's reactivity [33]

\section{Conclusion}

The results of phytochemical screening revealed that EtyAc fraction of Lannea acida contains flavonoids, tannins, alkaloids, phenols, steroids, terpenoids etc. It was found that significant amount of phenolic compounds which are responsible for free radical scavenging activity were detected in the EtyAc fraction and also its free radical scavenging activity increased with increasing concentration of plant extract.

\section{References}

[1] I. Gulcin, M.E. Buyukokuroglu, M. Oktay, O.I. Kufrevioglu, On the invitro antioxidant properties of melatonin, J. Pineal Res. 33 (2002) 167-171.

[2] H.R. Jadhav, K.K. Bhutani, Antioxidant properties of Indian medicinal Plants, Phyto. Res. 16 (2002) 771-773.

[3] M.G. Repetto, S.F. Llesuy, Antioxidant properties of natural compounds used in popular medicine for gastric ulcers, Braz. J. Med. Biol. Res. 5 (2002) 523-534.

[4] G. Rajat, D. Panchali, A study on antioxidant properties of different bioactive compounds, Jour. Drug Delivery Therap. 4 (2014) 105-115.

[5] E.A. Shalaby, M.M. Shanab, Antioxidant compounds, assays of determination and mode of action, Afr. J. Pharm. Pharmaco. 7 (2013) 528-539.

[6] M.M. Asugu, A.M. Mbahi, I.A. Umar, D.A. Ameh, I. Joseph, H. Louis, P.I. Amos, Phytochemical screening and antimicrobial activity of the pulp extract and fractions of Ziziphus mauritiana, Biochem. Anal. Biochem. 7 (2018) 1-6.

[7] J.J. Gao, K. Igalashi, M. Nukina, Radical scavenging activity of phenylpropanoid glycosides in Caryopteris incana, Biosci. Biotechnol. Biochem. 63 (1999) 983988.

[8] G.M. Williams, M.J. Iatropoulos, J. Whysner, Safety assessment of butylated hydroxyanisole and butylated hydroxyltoluene as antioxidant food additives, Food Chem. Toxicol. 37 (1999) 1027-1038.

[9] L.S. Gill, Ethno-medicine uses of plant in Nigeria, Beekeeping and Community Forest Management, University of Benin Press, Nigeria, 1992.

[10] H.M. Burkill, The useful plants of west tropical Africa, General Index, Royal Botanic Gardens, UK, 2004

[11] H. Ellenberg, H.E. Weber, R. Düll, V. Wirth, W. Werner, D. Paulissen, Pirrang: ecological investigation in Forest Island in the Gambia, Gambian Press, Gambia, 1998.

[12] S.W. Hassan, S. Verma, S.K. Srivastava, S. Luqman, U. Gupta, N. Masood, Activity guided isolation and characterization of antioxidant and antibacterial agents from some local Nigerian plants, Afri. J. Biotech. 12 (2013) 6315-6325.

[13] H.O. Edeoga, D.E. Okwu, B.O. Mbaebie, Phytochemical constituents of some Nigerian medicinal plants, Afr. J. Biotechnol. 4 (2005) 685-688

[14] A. Sofowora, Medicinal plant and traditional medicine in Africa, Spectrum books Limited, Lagos-Nigeria, 1993.

[15] G.E. Trease, W.C. Evans, Pharmacognosy, $13^{\text {th }}$ Edn., Bailliere Tindall, London, 1989

[16] J.B. Harborne, Phytochemical methods: A guide to modern techniques of plant Analysis, Chapman and Hall Ltd, London, 1973.

[17] H. Louis, O.U. Akakuru, M.N. Linus, J. Innocent, I.A. Pigweh, Qualitative and quantitative phytochemical analysis of Sclerocarya birrea and Sterculia setigera in Kem and Yola, Adamawa State, Nigeria, Adv. J. Biochem. Res. 6 (2018) 1-10.

[18] L.M. McCune, T. Johns, Antioxidant activity in medicinal plants associated with the symptoms of diabetes mellitus used by the indigenous peoples of the North American boreal forest, J. Ethnopharmacol. 82 (2002) 197-205.

[19] S. McDonald, P.D. Prenzler, M. Autolovich, K. Robards, Phenolic content and antioxidant activity of olive extracts, Food Chem. 73 (2001) 73-84.

[20] H. Louis, O.N. Maitera, G. Boro, J.T. Barminas, Determination of total phenolic content and some selected metals in extracts of Moringa oleifera, Cassia tora, Ocimum gratissimum, Vernonia baldwinii and Telfairia occidentalis plant leaves, World News Nat. Sci. 11 (2017) 11-18. 
[21] D. Kumar, S. Kottai, A. Muthu, R. Manavalan, Antioxidant potential of various extracts from whole plant of Ionidium suffruticosum (Ging), Res. J. Pharm. Biol. Chem. 2 (2011) 286-293.

[22] D.A. Okoth, H.Y Chenia N.A. Koorbanally, Antibacterial and antioxidant activities of flavonoids from Lannea alata (Engl.) Engl. (Anacardiaceae), Phytochem. Lett. 6 (2013) 476-481.

[23] P. Picerno, T. Mencherini, R. Della Loggia, M. Meloni, R. Sanogo, R.P. Aquino, An extract of Lannea microcarpa: composition activity and evaluation of cutaneous irritation in cell cultures and reconstituted human epidermis, J. Pharm. Pharm. 58 (2006) 981-988.

[24] E.F. Queiroz, C. Kuhl, C. Terreaux, S. Mavi, K. Hostettmann, New dihydroalkylhexenones from Lannea edulis, J.Nat.Prod. 66 (2003) 578-580.

[25] T. Okuda, Systematics and health effects of chemically distinct tannins in medicinal plants, Phytochem. 66 (2005) 2012-2031.

[26] G. Di Carlo, N. Mascolo, A.A. Izzo, F. Capasso, Flavonoids: old and new aspects of a class of natural therapeutic drugs, Life Sci. 64 (1999) 337-353.

[27] C. La Casa, I. Villegas, C. Alarcon De La Lastra, V. Motilva, M.J. Martin, Evidence for protective and antioxidant properties of rutin, a natural flavone, against ethanol induced gastric lesions, J. Ethnopharmacol. 71 (2010) 45-53.
[28] J.F. Ferreira, D.L. Luthria, T. Sasaki, A. Heyerick, Flavonoids from Artemisia annua L. as antioxidants and their potential synergism with artemisinin against malaria and cancer, Molecules 15 (2010) 3135-3170.

[29] H.K. Sandhar, B. Kumar, S. Prasher, P. Tiwari, M. Salhan, P. Sharma, A review of phytochemistry and pharmacology of flavonoids, Int. Pharm. Sci. 1 (2011) 2441.

[30] H.S. Falcão, J.A. Leite, J.M. Barbosa-Filho, P.F. de Athayde-Filho, M.C.O. Chaves, M.D. Moura, et al., Gastric and duodenal antiulcer activity of alkaloids: a review, Molecules 13 (2008) 3198-3223.

[31] A.A. Dehpour, M.A. Ebrahimzadeh, S.F. Nabavi, S.M. Nabavi, Antioxidant activity of methanol extract of Ferula assafoetida and its essential oil composition, Agri. Sci. Tech. 60 (2009) 405-412.

[32] M.A. Ebrahimzadeh, F. Bahramian, Antioxidant activity of Crataegus pentagina subsp. elbursis fruits extracts used in traditional medicine in Iran, Pak. J. Biol. Sci.12 (2009) 413-419.

[33] R.L. Prior, X. Wu, K. Schaich, Standardized methods for the determination of antioxidant capacity and phenolics in foods and dietary supplements, J. Agri. Food Chem. 53 (2005) 4290-302. 